\title{
The impact of social and relational contexts on innovation transfer in foreign subsidiaries
}

Article

Accepted Version

Bezerra, M. A. and Borini, F. M. (2015) The impact of social and relational contexts on innovation transfer in foreign subsidiaries. International Journal of Learning and Intellectual Capital, 12 (1). pp. 16-31. ISSN 1479-4861 doi: https://doi.org/10.1504/IJLIC.2015.067823 Available at https://centaur.reading.ac.uk/37959/

It is advisable to refer to the publisher's version if you intend to cite from the work. See Guidance on citing.

To link to this article DOI: http://dx.doi.org/10.1504/IJLIC.2015.067823

Publisher: Inderscience

All outputs in CentAUR are protected by Intellectual Property Rights law, including copyright law. Copyright and IPR is retained by the creators or other copyright holders. Terms and conditions for use of this material are defined in the End User Agreement.

www.reading.ac.uk/centaur 
Central Archive at the University of Reading

Reading's research outputs online 


\section{THE IMPACT OF SOCIAL AND RELATIONAL CONTEXTS ON INNOVATION TRANSFER IN FOREIGN SUBSIDIARIES}

\section{MAITE ALVES BEZERRA}

PhD student Department of International Business and Strategy

Henley Business School - University of Reading

Whiteknights, Reading, Berkshire, RG6 6AH, United Kingdom

E-mail: m.alvesbezerra@pgr.reading.ac.uk or maiteabezerra@gmail.com

Phone: +44 (0) 7939136881

*Corresponding author

\section{FELIPE MENDES BORINI}

Associate Professor Department of International Business Studies

Escola Superior de Propaganda e Marketing (ESPM-SP)

São Paulo - SP, Brazil, R. Álvaro Alvim, 123

Vila Mariana - ZipCode: 04018-010

E-mail: fborini@espm.br

Professor University of São Paulo

Department of Business Studies,

São Paulo - SP, Brazil, Av. Prof. Luciano Gualberto, 908

Cidade Universitária - ZipCode: 05508-010

\section{BIOGRAPHICAL NOTES:}

Maitê Bezerra is a PhD Student in International Business and Strategy at Henley Business School University of Reading. Her main research interests are strategies and innovation in emerging market multinationals.

Felipe Borini is Associate Professor of Global Strategy at ESPM-SP and Professor in the Department of Business Studies at University of São Paulo. He has PhD in Business Administration at University of Sao Paulo (USP). His main research interests are strategies and innovation in foreign subsidiaries. 


\begin{abstract}
It is widely acknowledged that innovation is one of the pillars of multinational enterprises (MNEs) and that technological knowledge from different host locations is a key factor to the MNEs' competitive advantages development. Concerning these assumptions, in this paper we aim to understand how the social and the relational contexts affect the conventional and reverse transfer of innovation from MNEs' subsidiaries hosted in emerging markets. We analyzed the social context through the institutional profile (CIP) level and the relational context through trust and integration levels utilizing a survey sent to 172 foreign subsidiaries located in Brazil, as well as secondary data. Through an ordinary least squares regression (OLS) analysis we found that the relational context affects the conventional and reverse innovation transfer in subsidiaries hosted in emerging markets. We however did not find support for the social context effect.
\end{abstract}

\title{
INTRODUCTION
}

Traditionally, the subsidiaries had the function to manage the product life cycle (Vernon, 1966) limiting their production chain activities only to product adaptation (Cantwell \& Mudambi, 2005; Castellani, Jimenez, \& Zanfei, 2013) and commercialization (Amatucci \& Bernardes, 2009). Because of the high cost of innovation process coordination developed out of headquarters, MNEs tended to concentrate their investments on innovation at their origin country. Therefore, the subsidiaries were responsible for less strategic activities, requiring less management efforts (Zanfei, 2000).

The development of a global economy and increasing relevance of emerging markets, however, stimulated the rising competition in global markets, forcing changes in MNEs' strategy (Bartlett \& Ghoshal, 1989; V. Govindarajan \& Ravi Ramamurti, 2011; Yip, 1989). These changes in the global scenario made MNEs seek not only consumer market expansion and cost reduction on their internationalization process, but also technological knowledge as well as innovations in their subsidiaries abroad (Borini, Costa, Bezerra, \& Oliveira Jr, 2014; Borini, Oliveira Júnior, Silveira, \& Concer, 2012; Govindarajan, 2012).

Innovation is one of the bases to MNEs' existence (Bartlett \& Ghoshal, 1989; V. Govindarajan \& Ravi Ramamurti, 2011) and innovation transfer is one of the key factors of MNEs' competitive advantage (Bartlett \& Ghoshal, 1989; Borini et al., 2014; Borini et al., 2012; V. Govindarajan \& Ravi Ramamurti, 2011). However, the internationalization process of innovation occurred more slowly than the globalization process (Archibugi \& Iammarino, 2002; Castellani et al., 2013; Picci, 2010; Zanfei, 2000). This fact motivated us to explore the innovation transfer process from headquarters to subsidiaries (Schleimer \& Pedersen, 2013) as well as from subsidiaries to headquarters (Borini et al., 2014; Borini et al., 2012; Immelt, Govindarajan, \& Trimble, 2009). Although there are some studies about innovative capabilities' transfer in an emerging markets context, (Ariffin \& Figueiredo, 2003; Figueiredo, 2011; Figueiredo \& Brito, 2011) they are still rare in Brazil.

To examine the phenomenon of organizational practices' transfer within MNEs, Kostova (1999) used a cross-disciplinary approach and developed a multilevel model of transfer success. The author proposed that the organizational, social, and relational contexts impact the successful transfer. We believe that this same pattern can be used for the transfer of innovation, although we will analyze only the social and relational contexts. Thus, we argue that the social context, at the level of institutional environment, and the relational context, at the level of integration and trust, affect the traditional and reverse transfer of innovation.

The information in this paper allows us to contribute to the international business theory, once innovation development and transfer are treated as key factors of MNEs' competitive advantage (Bartlett \& Ghoshal, 1989; Borini et al., 2014; Borini et al., 2012; V. Govindarajan \& Ravi Ramamurti, 2011), especially to the rising field of innovation in emerging markets (Cuervo-Cazurra, 2012; Edquist, 1997; Immelt et al., 2009; Johnson \& Lundvall, 2003; Nelson, 2006; Ramamurti, 2008). We also contribute to systems of innovation (SIs) literature, where most of the studies are focused on the context of developed countries (Lundvall, Johnson, Andersen, \& Dalum, 2002). At the managerial level, findings of this paper can assist managers in better understanding strategies to foster innovation transfer, especially in emerging markets. 
This paper is structured as follows. In the first section is the theoretical framework, including all constructs and the relationships of interest. Subsequently, we introduce the description of the hypotheses, establishing the relationship between social and relational context and innovation transfer. The methodology presents the principles of the OLS used and we finally conclude with the results and a discussion section.

\section{THEORETICAL FRAMEWORK}

Innovation can be defined as a "new combination of factors" (Schumpeter, 1939, p. 85) or a process by which firms put into practice products and process that are new to them (Nelson, 1993). In 1997, the Oslo Manual introduced a broad concept, which included not only product and process innovation, but also organizational and marketing innovations. To generate innovations, firms need to acquire technological capabilities, which are defined as a process of complex learning (Kim, 1997), through resources such as skills, knowledge and experience, institutional structure, and linkages within, between, and outside companies (Bell \& Pavitt, 1997).

It is widely acknowledged that innovation is the main feature in economic development (Nordman, 2012; Patel \& Pavitt, 1991; Schumpeter, 1928) and is one of the bases to MNEs' existence (Bartlett \& Ghoshal, 1989; V. Govindarajan \& Ravi Ramamurti, 2011). Traditionally MNEs' technological activities were centered on a parent company (Castellani et al., 2013; Patel \& Pavitt, 1991; Picci, 2010; Vernon, 1966), and the relationship between parent-subsidiary was classified as a colonial relationship (Vernon, 1966). There were many reasons for that, including the fact that innovation processes were expensive and difficult to manage, especially when developed outside the parent company (Vernon, 1966), the lack of high technology in foreign countries (Patel \& Pavitt, 1991), and the fact that technological activities are directly related to a firm's value creation (Castellani et al., 2013). This led Patel and Pavitt (1991, p. 17) to conclude that "the production of technology remains far from globalized."

Since then the scenario has changed, through advances in institutional environment, as intellectual property rights protection laws, and the increasing international collaboration (Picci, 2010), as knowledge transfer. However, some studies show that the internationalization process of innovation occurred in a slower manner than the globalization process of markets and production (Archibugi \& Iammarino, 2002; Picci, 2010; Zanfei, 2000). This emphasizes the relevance of studying this phenomenon once many authors recognized that one of the main advantages of MNEs is their ability to explore and transfer knowledge and technology from different geographic locations (Gupta \& Govindarajan, 2000; Schleimer \& Pedersen, 2013; Tallman \& Chacar, 2011) within their internal network more efficiently and effectively than would occur through market mechanisms (Almeida, Song, \& Grant, 2002; Borini et al., 2014; Borini et al., 2012; Buckley \& Casson, 2009; Kogut \& Zander, 1993; Michailova \& Mustaffa, 2012). As pointed out by Meyer, Mudambi, and Narula (2011), the increasing globalization did not lead to the homogeneity of markets and knowledge from host locations became the source of competitive advantage to MNEs.

The lack of high technology in foreign countries was what led earlier studies to assume that innovation originates in developed countries, where headquarters are usually located, once these countries have well-developed SIs (Bell \& Pavitt, 1995; Utterback \& Abernathy, 1975; Vernon, 1966). But there is a growing number of studies showing that innovation can originate in emerging markets too (Fleury, Fleury, \& Borini, 2013; V. Govindarajan \& Ravi Ramamurti, 2011; Hobday, 2005; Kim, 1997; Prahalad \& Mashelkar, 2010; Ramamurti, 2008; Reddy, 2000; Vernon-Wortzel \& Wortzel, 1988), where subsidiaries are usually located. So innovations can be developed both at headquarters and at subsidiaries and their transfer can occur in several directions (Borini et al., 2012). To explore technological knowledge from different locations, MNEs need to ensure the transfer of this knowledge to and from different subsidiaries to and from the home country (Castellani et al., 2013).

In this way, technological knowledge can be transferred from headquarters to subsidiaries (Kostova, 1999; Schleimer \& Pedersen, 2013), which is termed conventional transfer of knowledge (Yang, Mudambi, \& Meyer, 2008), and from the subsidiaries to other units, including headquarters (Ambos, Ambos, \& Schlegelmilch, 2006; Borini et al., 2014; Borini et al., 2012; McGuinness, Demirbag, \& Bandara, 2013; Mudambi, Piscitello, \& Rabbiosi, 2007; Rabbiosi, 2011), which is termed reverse transfer of knowledge (Yang et al., 2008). 
Conventional transfer is a key factor to MNEs' survival, because it affects the way in which headquarters leverage their advantages abroad. At the subsidiary level, headquarters' knowledge enables units to respond successfully to the challenges faced in their host country environment (Schleimer \& Pedersen, 2013). On the other hand, reverse transfer of knowledge may be a source of competitive advantage to the MNE as a whole (Yang et al., 2008), since it enables MNEs to access a variety of local knowledge and technology (Borini et al., 2014; Borini et al., 2012). At the subsidiary level, it can leverage their strategic position within internal networks (Borini et al., 2012; Cantwell, Dunning, \& Lundan, 2010).

\section{SOCIAL CONTEXT: INSTITUTIONAL ENVIRONMENT}

One factor that affects the successful transfer of practices is the social context, since there are country-level effects. This means that some countries provide a more favorable environment for transfer of certain practices than others (Kostova, 1999). Within the innovation literature context, authors clearly show the influence of the environment on innovation development.

Concerning SIs perspective, it is widely acknowledged that a well-developed institutional environment leads to the development of a company's innovative ability (Edquist, 1997, 2005; Freeman, 1995; Johnson \& Lundvall, 2003; Nelson, 2006). Thus firms need to establish external linkages to provide innovations (Edquist, 1997; Freeman, 1995; Lundvall et al., 2002).

The innovation process is influenced by a vast range of factors, policies, and organizations (Nelson, 1993) and its success relies not only on formal R\&D, but a wide variety of other factors as well as links with national education systems (Hospers \& Benneworth, 2012), scientific and technical institutions, and government (Freeman, 1995). These external factors by which firms need to establish linkages to provide innovations are defined as SIs (Edquist, 1997, 2005; Freeman, 1995; Lundvall et al., 2002). Through this perspective, lower innovation rates can be explained by damaged educational systems, weak enterprise-level $R \& D$, weak technology transfer integration, weak scientific infrastructure, and poor linkages with industry (Freeman, 1995).

With the growing relevance of emerging economies (Cuervo-Cazurra, 2012; Guillén \& GarcíaCanal, 2009; Luo \& Tung, 2007; Mathews, 2006; Ramamurti, 2008), innovation in these countries became the subject of study and many authors concluded that the environment of these countries can also generate innovations (Figueiredo \& Brito, 2011; Fleury et al., 2013; V. Govindarajan \& R. Ramamurti, 2011; Wu, Ma, \& Xu, 2009; Zhao \& Richards, 2012). A successful combination of constraints and ambition is the key factor of innovation for companies in emerging markets (Prahalad \& Mashelkar, 2010) that are offering pioneering business applications to dramatically lower costs (Immelt et al., 2009).

Consequently, it is possible to conclude that both types of environments lead to innovation. However, what happens when innovations are transferred across different institutional environments? Countries' institutional environments may differ in regulatory, cognitive, and normative pillars (Peng, Wang, \& Jiang, 2008; Scott, 2008), defined by Kostova (1999) as CIP. The greater the difference between institutional environments, the greater the difficulties or even failure of the transfer (Kostova, 1999), once it creates barriers on a common language establishment and on knowledge absorption (Castellani et al., 2013).

Without detailed knowledge about foreign environments, it's difficult to assess whether knowledge is transferable abroad (Cantwell et al., 2010), thus high institutional distance creates uncertainty on knowledge transfer (Tallman \& Chacar, 2011) affecting the internal knowledge flow (Castellani et al., 2013). Therefore MNEs prefer similar institutional environments (Cuervo-Cazurra, 2006). Kostova (1999) proposed that success of conventional practices' transfer is positively related to CIP similarities between units involved in the transfer process. We therefore propose:

H1a: The higher the similarities between headquarters and subsidiaries' CIP, the higher the reverse transfer of innovations.

H1b: The higher the similarities between headquarters and subsidiaries' CIP, the higher the conventional transfer of innovations.

\section{RELATIONAL CONTEXT: TRUST AND INTEGRATION}


When environment characteristics are favorable to knowledge transfers, they can still fail because of specific relationships between aspects involved in the process (Kostova, 1999). MNEs interact with multiple and heterogeneous host locations where units are located, as well as their internal hierarchy (Meyer et al., 2011). MNEs' units, thus have the potential to embed themselves in different internal and external knowledge networks to build up innovative capabilities (Figueiredo, 2011; Nordman, 2012).

The embeddedness perspective indicates that social relations created with different actors in social environments facilitate a firm's competitive advantage development (Figueiredo, 2011; Granovetter, 1985; Uzzi, 1996) and create unique opportunities (Uzzi, 1996). The relational embeddedness treats the extent to which individual and direct subsidiaries' relationships with actors (suppliers, customers, competitors, etc.) can serve as a source of learning. Emphasizing that interfirm linkages embedded in social relations and networks leverage a firm's capabilities and competences, and create a basis for knowledge transfer between actors (Figueiredo, 2011; Uzzi \& Gillespie, 2002).

Innovative capabilities from MNEs' units are positively associated with their knowledge exchange within internal networks (Andersson, Forsgren, \& Holm, 2002). These relationships are based on trust and reciprocity, so the features of organizational embeddedness ties are trust and integration (Uzzi, 1996).

Firms can leverage their capabilities through internal linkages and informal mechanisms, as trust can facilitate resource transfers between units (Uzzi \& Gillespie, 2002). Trust is a single governance mechanism that is personal and can leverage access to resources. It helps reduce uncertainty, creating opportunities for exchanges, facilitating information exchanges that are fundamental to high performance (Uzzi, 1996), and promoting value creation (Uzzi \& Gillespie, 2002). Knowledge-intensive transfers are generally composed of relations based on trust (Figueiredo, 2011).

According to Kostova (1999), trust in the parent company is one of the features of relationships that affects motivation, and thus the success of practices' transfer on the relational context. We will use this perspective, however arguing that the parent must trust in subsidiaries. We propose this inverse relation once we are analyzing not only the conventional innovation transfer but also the reverse innovation process that, as affirmed by (Yang et al., 2008), is a persuasion process subsidiaries must perform to convince headquarters of the relevance of their knowledge, which is only possible when the headquarters trusts in the subsidiary. On the other hand, trust is one of the organizational mechanisms that MNEs' parent can use to leverage subsidiary absorptive capacity in knowledge transfer processes (Schleimer \& Pedersen, 2013). We therefore propose:

H2a: The higher the headquarters' trust in subsidiaries, the higher the reverse transfer of innovations. $\mathrm{H} 2 \mathrm{~b}$ : The higher the headquarters' trust in subsidiaries, the higher the conventional transfer of innovations.

Integration in MNEs can be defined as the relationship of strategic alignment and interdependence between headquarters and their subsidiaries (Borini et al., 2012). The lack of integration creates barriers in technological knowledge transfer (Tallman \& Chacar, 2011), once this type of knowledge involves a high level of uncertainty, that is reduced with intensive communication, socialization, and trust (Borini et al., 2012; Nohria \& Ghoshal, 1997).

Schleimer and Pedersen (2013) empirically confirmed that integration is one of the mechanisms that conduces the diffusion of knowledge within an MNE internal network and fosters subsidiaries' absorptive capacity in traditional knowledge transfer. This way, the lack of internal embeddedness restricts the ability of innovation assimilation (Tallman \& Chacar, 2011).

Some authors have stressed the factors that affect the reverse transfer, particularly related to autonomy and integration between the subsidiary and headquarters (Ambos et al., 2006; Borini, 2010; Bresman, Birkinshaw, \& Nobel, 2010; Cavusgil, Knight, \& Riesenberger, 2008; Chini, 2004; Yang et al., 2008). According to Borini et al. (2014), there must be a strategic alignment between the headquarters and the subsidiaries, i.e., integration, so that the innovation developed in subsidiaries can be accepted and used by headquarters and other units. This alignment is achieved through integration. Borini et al. (2012) confirmed empirically the relevance of innovation on reverse transfer of knowledge. We therefore propose: 
H3a: The higher the integration between headquarters and their subsidiaries, the higher the reverse transfer of innovations.

$\mathrm{H} 3 \mathrm{~b}$ : The higher the integration between headquarters and their subsidiaries, the higher the conventional transfer of innovations.

\section{METHODOLOGY}

To address our research question, verify the impact of social and relational contexts on conventional and reverse innovation transfer through a multilevel model of transfer success proposed by Kostova (1999), we used primary and secondary data. The primary data were gathered through a field survey. The sample was chosen based on companies' revenues, using a research base comprised of the 1,200 largest multinational companies of foreign capital operating in Brazil. Companies' names were provided by Análise Editorial, which publishes the Annual Foreign Trade Analysis. The data were collected through questionnaires sent to the Chief Executive of each subsidiary via e-mail, with telephone follow-up. Although 1,200 questionnaires were sent, after the contact by phone we found that the mailing contained some repeated addresses and incorrect contact information. Therefore, our research base was reduced to 1,012 subsidiaries. From these, 181 responded; however, 9 responses were excluded due to incomplete or incorrect data. The final sample comprised 172 foreign subsidiaries hosted in Brazil, a 17\% response rate. This percentage was expected and proved equivalent, for example, to the research undertaken by Oliveira $\mathrm{Jr}$, Boehe, and Borini (2009) when studying foreign subsidiaries hosted in Brazil. Secondary data were gathered through World Bank.

OLS regression analysis was chosen as the statistical method for data analysis. Once we had an explanatory aim for this paper we expected to examine the importance of independent variables and the relationships between them (Hair Jr, Black, Babin, Anderson, \& Tatham, 2009). Based on the hypotheses presented above, the dependent and independent variables of this study are presented below.

\section{Dependent variables}

The construct reverse transfer of innovation (S-H) was based on Bell and Pavitt (1995); Borini et al. (2012); OECD (1997) and assesses the development and/or transfer of innovation capabilities from the subsidiary in terms of (v1) research and development; (v2) marketing; (v3) production; (v4) human resources; and (v5) procurement. Convergent validity was high (Cronbach's $\alpha=0.77$ ).

The construct conventional transfer of innovation (H-S) was based on Kostova (1999); OECD (1997) and assesses the headquarters' influence on (v6) research and development; (v7) marketing; (v8) production; (v9) human resources; and (v10) procurement activities. Convergent validity was high (Cronbach's $\alpha=0.68)$.

\section{Independent Variables}

We measured the social context through the CIP construct based on Kostova (1999); Scott (2008). This construct assesses a country's institutional level through (v20) government legitimacy; (v21) political stability; (v22) government effectiveness; (v23) regulatory environment; (v24) legal environment; and (v25) corruption control. We measured this construct by averaging these six items above, obtained from the World Bank database. These variables were standardized to fit the remaining variables.

We measured the relational context (Kostova, 1999) through trust and integration constructs. The integration construct was based on Birkinshaw, Hood, and Jonsson (1998); Borini et al. (2012) and assesses if in the relationship between headquarters and the subsidiary there exists (v13) a strong working relationship; (v14) substantial knowledge exchange; (v15) a large number of subsidiary's executives traveling to headquarters; and (v16) a large number of expatriates in Brazil. Convergent validity was high (Cronbach's $\alpha=0.71$ ). The trust construct was based on Figueiredo (2011); Uzzi (1996); Uzzi and Gillespie (2002) and assesses whether in the headquarter-subsidiary relationship there is (v17) support for risk 
decisions taken by the subsidiary; (v18) support for a subsidiary's entrepreneurial activities; and (v19) trust in the subsidiary. Convergent validity was high (Cronbach's $\alpha=0.80$ ).

\section{RESULTS}

The results of Pearson's correlation coefficients are presented in Table 1. They indicate that CIP variable has no significant correlation with the dependent variables; through Pearson's correlation analysis this variable has no significant contribution to the proposed relations. Therefore, this indicates that hypotheses H1a, b and c will probably not be supported.

\section{INSERT TABLE 1 and 2}

The model's collinearity was measured using VIF test (see Table 2), which ensures the absence of multicollinearity among the variables when smaller than 5 (Hair Jr et al., 2009). In Table 2 we tested the Hypotheses using OLS regressions. The analysis was made through reverse transfer of innovation (H1a, $\mathrm{H} 2 \mathrm{a}$ and $\mathrm{H} 3 \mathrm{a}$ ) and conventional transfer of innovation ( $\mathrm{H} 1 \mathrm{~b}$ and $\mathrm{H} 2 \mathrm{~b} \mathrm{H} 3 \mathrm{~b}$ ) perspectives.

The reverse transfer of innovation perspective "S- $\mathrm{H}$ " has the following general equation: $\mathrm{S}-\mathrm{H}=$ $0.912+0.345$ integration +0.173 trust +0.014 CIP. Table 2 shows the positive and significant impact, at a level of $\mathrm{p}<0.01$, of the integration on "S- $\mathrm{H}$ " and the positive and marginally significant impact, at a level of $\mathrm{p}<0.10$, of the trust in the subsidiary on "S-H". Thus, hypothesis H3a was significantly supported and $\mathrm{H} 2 \mathrm{a}$ was marginally supported. The hypothesis H1a was not supported. The "S-H" model attained an adjusted $\mathrm{R}^{2}$ value of $17.4 \%$ that is quite satisfactory given the complexity of the phenomenon studied.

The conventional transfer of innovation perspective " $\mathrm{H}-\mathrm{S}$ " has the following general equation: $\mathrm{H}$ $\mathrm{S}=2.063+0.515$ integration -0.155 confidence $-0.022 \mathrm{CIP}$. Table 2 shows the positive and significant impact, at a level of $\mathrm{p}<0.01$, of the integration on " $\mathrm{H}-\mathrm{S}$ " and the negative and marginally significant impact, at a level of $\mathrm{p}<0.10$, of the trust in the subsidiary on "H-S". Thus, hypothesis H3b was significantly supported and $\mathrm{H} 2 \mathrm{~b}$ was inversely and marginally supported. The hypothesis H1b was not supported. The " $\mathrm{H}-\mathrm{S}$ " model attained an adjusted $\mathrm{R}^{2}$ value of $21.4 \%$ that is quite satisfactory given the complexity of the phenomenon studied.

Due the results, we did not find support for the social context impact, at the level of institutional environment and a CIP perspective, on conventional and reverse transfer of innovation in our sample.

\section{DISCUSSION}

Concerning the data analysis, some reflections of the results are relevant; once we found support for only some hypotheses we proposed.

First we will address the issue of headquarters' trust in its subsidiary. A positive relationship of trust in a subsidiary provides some degree of autonomy, credibility, and freedom to the unit to respond to local forces that require local responsiveness. With the adaptation process to local demands the subsidiary is stimulated to develop innovations and, the autonomy provided by headquarters allows their effective development. Therefore, trust in a subsidiary fosters the reverse transfer of innovation and its implementation on headquarters, which fundamentally requires high credibility in subsidiary capabilities.

However, the opposite is also true, if the headquarters does not have trust in the subsidiary, the headquarters will tend to impose their innovative capabilities on the subsidiary structure, increasing the flow of innovation from headquarters to the subsidiary within the MNE internal network, i.e., conventional transfer of innovation. This explains the inverse support we found for H2b.

Another issue addressed in the paper is the relational integration between headquarters and subsidiaries, which is consolidated through constant flow of information and employees within MNEs' internal network. The main aim of the integration process is the transfer of knowledge between MNEs' units, disseminating best practices and innovation capabilities to contribute to the development of competitive advantages. 
The integration factor is closely related to the internal embeddedness, and the higher the units' internal embeddedness, the higher the transfer of information between them. This high flow of information leverages the subsidiary's innovation development since the unit has access to inputs that contribute to its strategy improvement. These inputs foster its ability to adapt to the local environment thus stimulating the development of innovative practices. The innovation flow between companies brings beneficial results for both parties and thus to the MNE structure as a whole. Therefore, the integration stimulation is essential to the establishment of an effective and cohesive corporate structure, once it enables the innovation flow in both directions, from headquarters to the subsidiary and vice versa.

Finally, the CIP effect on innovation development and transfer was not supported. It is fundamental to highlight that it does not mean that the social context proposed by Kostova (1999) has no impact on innovation development and transfer. It means that the CIP construct we used has no significant relevance in the data we analyzed. However one possible explanation for this result is that these companies continue to use the traditional strategic model of internationalization (Vernon, 1966; Zanfei, 2000), so the headquarters imposes their strategies according to its home country, overlapping any host country environment influences. Nevertheless, this is only one consideration that needs future researches to be better explored.

\section{CONCLUSION}

This paper shows that the strategic role of a subsidiary within the MNE structure is directly affected by the relational context, through integration and trust perspective. Once it decisively contributes to defining the relationship between the parent and their subsidiaries, the strategic role of the subsidiary is determined. If there is a trustful and highly integrated relationship between MNEs' headquarters and the subsidiaries, the subsidiaries will have autonomy to develop strategic roles on MNEs' innovation development process and also act as a local representative of the MNE. On the other hand, if there is no closeness and trust in this relationship the subsidiary will adopt a strategic role as a mere MNE local operator. In this case, the innovation development is low, if not null, and practices and strategies are simple replications of headquarters' global strategy.

The results in this paper contribute to the international business theory, once innovation and innovation transfer are key factors of MNEs' competitive advantage (Bartlett \& Ghoshal, 1989; Borini et al., 2014; Borini et al., 2012; V. Govindarajan \& Ravi Ramamurti, 2011). Since the subsidiaries of our sample were hosted in Brazil, this paper also contributes to the rising number of studies that analyze innovation development and transfer process in emerging countries (Cuervo-Cazurra, 2012; Edquist, 1997; Immelt et al., 2009; Johnson \& Lundvall, 2003; Nelson, 2006; Ramamurti, 2008). Helping provide depth to this research field since, as postulated by Ramamurti (2008, p. 10), "It took many years of research to identify and empirically confirm the firm-specific advantages of Western MNEs, and an equally diligent effort is necessary to uncover the firm-specific advantages of EMNEs." Finally, this study contributes to SI literature, since the studies on this research field are mainly focused on developed countries' reality (Lundvall et al., 2002).

At the managerial level, our findings can help to simplify the process of strategy choice to MNEs that have subsidiaries operating in Brazil or in other emerging markets. These results can also benefit managers by offering a better understanding of the organizational mechanisms that can be used to foster MNEs' innovative capabilities and thus develop competitive advantages, once the empirical results show that the relational and social context should be treated differently. This gap must be filled since existing empirical studies fail to provide guidance about organizational mechanisms that support knowledge management (Mariano, 2013) as well as the absorption and implementation of transferred knowledge (Schleimer \& Pedersen, 2013).

It is recognized that one of the main advantages of MNEs is their ability to explore and transfer knowledge and technology from different geographic locations (Gupta \& Govindarajan, 2000; Schleimer \& Pedersen, 2013; Tallman \& Chacar, 2011). Nevertheless some studies show that the internationalization process of innovation practices occurred more slowly than the globalization process of markets and production (Archibugi \& Iammarino, 2002; Picci, 2010; Zanfei, 2000). As, at the reverse transfer of innovation level, the results confirmed the relational context (Kostova, 1999) as a key factor influencing 
the process. Future researches could verify whether it is the poor management of an MNE's internal structure or the low level of internal embeddedness that is still the main barrier to the internationalization of the innovation process, even with the technological advance of communication tools.

This study is in line with the model proposed by Bartlett and Ghoshal (1989) once it is possible to establish a link between the relational context development (Kostova, 1999) and the transnational strategy. The well-developed relational context provides autonomy to the subsidiary, allowing the development of innovation.

Finally, regarding the validity of the multilevel model of transfer success proposed by (Kostova, 1999), we found support only for the relational context. We did not analyze the organizational context and we did not find support, in our results, for the social context effect. This can be justified by the impact of globalization on business, since that constant exchange of employees, technology and information changes, and joint strategies with headquarters are getting easier, decreasing the host country's environment dependency. However, some authors (Berry, Guillén, \& Zhou, 2010; Cantwell \& Zhang, 2011; Figueiredo \& Brito, 2011; V. Govindarajan \& Ravi Ramamurti, 2011) state that local environment affects the innovation development and transfer. Thus, we believe that this assumption needs to be better explored, perhaps through a dual embeddedness perspective (Figueiredo, 2011; Meyer et al., 2011).

As most of the empirical researches, this study has limitations. Our sample was limited to subsidiaries hosted only in Brazil, thus the results may be related to the specific reality of that country. Other limitations are the sample size and the fact that the survey questionnaires were answered by a single respondent in each company, thus the answers may be a result of the respondent's perception.

Our aim was to test the model proposed by (Kostova, 1999) but, since this is an empirical study with delimited sample size, it was not possible to test all the complete model. So, future researches could test the organizational context that was missed in this paper and the social and relational contexts through other perspectives proposed by the author. Another interesting suggestion of future research would be the study of the performance of Brazilian subsidiaries abroad, which could be analyzed through the social and organizational context perspective.

\section{REFERENCES}

Almeida, P., Song, J., \& Grant, R. M. (2002). Are firms superior to alliances and markets? An empirical test of cross-border knowledge building. Organization Science, 13(2), 147-161.

Amatucci, M., \& Bernardes, R. C. (2009). Impacto do desenvolvimento de produtos sobre a estratégia da subsidiária: Dois casos no setor automotivo brasileiro. Revista P\&D em Engenharia de Produção, 07(01), 20-36.

Ambos, T., Ambos, B., \& Schlegelmilch, B. (2006). Learning from foreign subsidiaries: An empirical investigation of headquarters benefits from reverse knowledge transfers. International Business Review, 15(3), 294-312.

Andersson, U., Forsgren, M., \& Holm, U. (2002). The strategic impact of external networks: subsidiary performance and competence development in the multinational corporation. Strategic Management Journal, 23(11), 979-996.

Archibugi, D., \& Iammarino, S. (2002). The globalization of technological innovation: definition and evidence. Review of International Political Economy, 9(1), 98-122. doi: 10.1080/09692290110101126

Ariffin, N., \& Figueiredo, P. N. (2003). Internationalization of innovative capabilities: Counter-evidence from the electronics industry in Malaysia and Brazil. Paper presented at the Paper for DRUID Summer Conference, Copenhagen.

Bartlett, C. A., \& Ghoshal, S. (1989). Managing across borders : the transnational solution. Boston: Harvard Business School Press.

Bell, M., \& Pavitt, K. (1995). The development of technological capabilities. In I. Ul Haque, M. Bell, C. Dahlman, S. Lall \& K. Pavitt (Eds.), Trade, technology and international competitiveness (pp. 69-101). Washington, DC: The World Bank.

Bell, M., \& Pavitt, K. (1997). Technological accumulation and industrial growth: contrasts between developed and developing countries. In D. Archibugi \& J. Michie (Eds.), Technology, globalization and economic performance (pp. 83-117). Cambridge: Cambridge University Press.

Berry, H., Guillén, M. F., \& Zhou, N. (2010). An Institutional Approach to Cross-National Distance. Journal of International Business Studies, 41, 1460-1480. 
Birkinshaw, J., Hood, N., \& Jonsson, S. (1998). Building Firm-Specific Advantages in Multinacional Corporations: The Role of Subsidiary Initiative. Strategic Management Journal, 19(3), 221-242.

Borini, F. M. (2010). As estratégias das subsidiárias brasileiras no exterior (Strategies of Brazilian subsidiaries abroad). In A. Fleury (Ed.), Gestão empresarial para a internacionalização das empresas brasileiras (Business management for Brazilian companies internationalization) (Vol. 1, pp. 83-100). São Paulo: Atlas.

Borini, F. M., Costa, S., Bezerra, M. A., \& Oliveira Jr, M. M. (2014). Reverse innovation as an inducer of centers of excellence in foreign subsidiaries of emerging markets. International Journal of Business and Emerging Markets, in press.

Borini, F. M., Oliveira Júnior, M. M., Silveira, F. F., \& Concer, R. O. (2012). The Reverse Transfer of Innovation of Foreign Subsidiaries of Brazilian Multinationals. European Management Journal, 30(3), 219-231.

Bresman, H., Birkinshaw, J., \& Nobel, R. (2010). Knowledge Transfer in International Acquisitions. Journal of International Business Studies, 41(1), 5-20.

Buckley, P. J., \& Casson, M. C. (2009). The internalisation theory of the multinational enterprise: A review of the progress of a research agenda after 30 years. Journal of International Business Studies, 40(9), 1563-1580.

Cantwell, J., Dunning, J. H., \& Lundan, S. M. (2010). An evolutionary approach to understanding international business activity: The co-evolution of MNEs and the institutional environment. Journal of International Business Studies, 41(4), 567-586.

Cantwell, J., \& Mudambi, R. (2005). MNE competence-creating subsidiary mandates. Strategic Management Journal, 26(12), 1109-1128. doi: 10.1002/smj.497

Cantwell, J., \& Zhang, Y. (2011). Innovation and location in the multinational firm. International Journal of Technology Management, 54(1), 116-132. doi: 10.1504/ijtm.2011.038832

Castellani, D., Jimenez, A., \& Zanfei, A. (2013). How remote are R\&D labs? Distance factors and international innovative activities. Journal of International Business Studies, 44(7), 649-675. doi: $10.1057 /$ jibs.2013.30

Cavusgil, T., Knight, G., \& Riesenberger, J. (2008). International business: Strategy, management \& the new realities. New Jersey: Pearson Prentice Hall.

Chini, T. C. (2004). Effective Knowledge Transfer in Multinational Corporations. USA: Plagrave Macmillan.

Cuervo-Cazurra, A. (2006). Who Cares about Corruption? Journal of International Business Studies, 37(6), 807-822. doi: 10.2307/4540385

Cuervo-Cazurra, A. (2012). Extending theory by analyzing developing country multinational companies: Solving the Goldilocks debate. Global Strategy Journal, 2(3), 153-167. doi: 10.1111/j.20425805.2012.01039.x

Edquist, C. (1997). Systems of innovation approaches - their emergence and characteristics. In C. Equist (Ed.), Systems of Innovation Technologies, Institutions and Organizations (Vol. 1 - 29). London and Washington: Pinter.

Edquist, C. (2005). Systems of innovation. In J. Fagerberg, D. C. Mowery \& R. Nelson (Eds.), The Oxford handbook of innovation (pp. 181-208). New York: Oxford University Press.

Figueiredo, P. N. (2011). The role of dual embeddedness in the innovative performance of MNE subsidiaries: Evidence from Brazil. Journal of Management Studies, 48(2), 417-440.

Figueiredo, P. N., \& Brito, K. (2011). The innovation performance of MNE subsidiaries and local embeddedness: evidence from an emerging economy. Journal of Evolutionary Economics, 21(1), 141-165.

Fleury, A., Fleury, M. T. L., \& Borini, F. M. (2013). The Brazilian Multinationals' Approaches to Innovation. Journal of International Management, 19(3). doi: http://dx.doi.org/10.1016/j.intman.2013.03.003

Freeman, C. (1995). The 'National System of Innovation' in historical perspective. Cambridge Journal of Economics, 19(1), 5-24.

Govindarajan, V. (2012). A Reverse-Innovation Playbook: Insights from a company that developed products for emerging markets and then brought them back home. Harvard Business Review, april.

Govindarajan, V., \& Ramamurti, R. (2011). Reverse innovation, emerging markets, and global strategy. Global Strategy Journal, 1(3-4), 191-205. doi: 10.1002/gsj.23

Govindarajan, V., \& Ramamurti, R. (2011). Reverse innovation, emerging markets, and global strategy. Global Strategy Journal, 1(3-4), 191-205.

Granovetter, M. (1985). Economic action and social structure: The problem of embeddedness. American Journal of Sociology, 91(3), 481-510. 
Guillén, M. F., \& García-Canal, E. (2009). The American model of the multinational firm and the "new" multinationals from emerging economies. Academy of Management Perspectives, 23(2), 23-35.

Gupta, A., \& Govindarajan, V. (2000). Knowledge Flows within Multinational Corporation. Strategic Management Journal, 21(4), 473-496.

Hair Jr, J. F., Black, W. C., Babin, B. J., Anderson, R. E., \& Tatham, R. L. (2009). Análise Multivariada de Dados (Vol. 6). Porto Alegre: Bookman.

Hobday, M. (2005). Firm-level Innovation Models: Perspectives on Research in Developed and Developing Countries. Technology Analysis \& Strategic Management, 17(2), 121-146. doi: 10.1080/09537320500088666

Hospers, G.-J., \& Benneworth, P. (2012). Innovation in an old industrial region: The case of Twente. Int. J. Learning and Intellectual Capital, 9(1/2), 6-21. doi: 10.1504/IJLIC.2012.043978

Immelt, J. R., Govindarajan, V., \& Trimble, C. (2009). How GE is disrupting itself. Harvard Business Review, October, 56-65.

Johnson, B. H., \& Lundvall, B. J. (2003). Promoting innovation systems as a response to the globalising learning economy. In J. E. Cassiolato, H. M. M. Lastres \& M. L. Maciel (Eds.), Systems of Innovation and Development. Cheltenham: Elgar.

Kim, L. (1997). Imitation to innovation: The dynamics of Korea's technological learning. Cambridge, MA: Harvard Business School Press.

Kogut, B., \& Zander, U. (1993). Knowledge of the Firm and the Evolutionary Theory of the Multinational Corporation. Journal of International Business Studies, 24(4), 625-645.

Kostova, T. (1999). Transnational transfer of strategic organizational practices: A contextual perspective. The Academy of Management Review, 24(2), 308-324.

Lundvall, B.-Å., Johnson, B., Andersen, E. S., \& Dalum, B. (2002). National systems of production, innovation and competence building. Research Policy, 31(2), 213-231. doi: http://dx.doi.org/10.1016/S0048-7333(01)00137-8

Luo, Y., \& Tung, R. L. (2007). International expansion of emerging market enterprises: A springboard perspective. Journal of International Business Studies, 38(4), 481-498. doi: http://dx.doi.org/10.1057/palgrave.jibs.8400275

Mariano, S. (2013). Understanding the nature of knowledge: An empirical study of knowledge sharing in a knowledge intensive organisation. Int. J. Learning and Intellectual Capital, 10(2), 151-164. doi: 10.1504/IJLIC.2013.052908

Mathews, J. (2006). Dragon multinationals: New players in 21st century globalization. Asia Pacific Journal of Management, 23(1), 5-27. doi: 10.1007/s10490-006-6113-0

McGuinness, M., Demirbag, M., \& Bandara, S. (2013). Towards a multi-perspective model of reverse knowledge transfer in multinational enterprises: A case study of Coats plc. European Management Journal, 31(2), 179-195. doi: http://dx.doi.org/10.1016/j.emj.2012.03.013

Meyer, K., Mudambi, R., \& Narula, R. (2011). Multinational Enterprises and Local Contexts: The Opportunities and Challenges of Multiple Embeddedness. Journal of Management Studies, 48(2), 235-252. doi: 10.1111/j.1467-6486.2010.00968.x

Michailova, S., \& Mustaffa, Z. (2012). Subsidiary knowledge flows in multinational corporations: Research accomplishments, gaps, and opportunities. Journal of World Business, 47(3), 383-396. doi: http://dx.doi.org/10.1016/j.jwb.2011.05.006

Mudambi, R., Piscitello, L., \& Rabbiosi, L. (2007). Mandates and Mechanisms: Reverse Knowledge Transfer in MNEs. Paper presented at the Four decades of International Business at Reading: Looking to the future, Reading.

Nelson, R. (1993). National Innovation Systems: A comparative analysis. New York: Oxford University Press.

Nelson, R. (2006). Sistemas Nacionais de Inovação: retrospecto de um estudo. In R. Nelson (Ed.), As Fontes do Crescimento Econômico (Vol. Clássicos da Inovação, pp. 427- 467). Campinas: Unicamp.

Nohria, N., \& Ghoshal, S. (1997). The Differentiated Network: Organizing Multinational Corporations for Value Creation. San Francisco: Jossey-Bass Publishers.

Nordman, E. R. (2012). The innovative product development of internationalising SMEs. Int. J. Learning and Intellectual Capital, 9(3), 276-294. doi: 10.1504/IJLIC.2012.047288

OECD. (1997). Oslo Manual: The measurement of scientific and technological activities - Proposed guidelines for collecting and interpreting technological innovation data (pp. 35-54).

Oliveira Jr, M. M., Boehe, D. M., \& Borini, F. M. (2009). Estratégia e inovação em corporações multinacionais: A transformação das subsidiárias brasileiras. São Paulo: Saraiva. 
Patel, P., \& Pavitt, K. (1991). Large Firms in the Production of the World's Technology: An Important Case of "Non-Globalisation". Journal of International Business Studies, 22(1), 1-21. doi: $10.1057 /$ palgrave.jibs.8490289

Peng, M. W., Wang, D. Y. L., \& Jiang, Y. (2008). An institution-based view of international business strategy: a focus on emerging economies. Journal of International Business Studies, 39(5), 920 936.

Picci, L. (2010). The internationalization of inventive activity: A gravity model using patent data. Research Policy, 39(8), 1070-1081. doi: http://dx.doi.org/10.1016/j.respol.2010.05.007

Prahalad, C. K., \& Mashelkar, R. A. (2010). Innovation's Holy Grail. Harvard Business Review, 88(7/8), 132-141.

Rabbiosi, L. (2011). Subsidiary roles and reverse knowledge transfer: An investigation of the effects of coordination mechanisms. Journal of International Management, 17(2), 97-113. doi: http://dx.doi.org/10.1016/j.intman.2010.10.001

Ramamurti, R. (2008). What Have We Learned About Emerging-Market MNEs? Insights from a MultiCountry Research Project. Paper presented at the Emerging Multinationals: Outward FDI from Emerging and Developing Economies, Copenhagen, Denmark.

Reddy, P. (2000). The Globalization of Corporate R\&D: Implications for Innovation Capability in Developing Host Countries. New Fetter Lane, London: Routledge.

Schleimer, S. C., \& Pedersen, T. (2013). The Driving Forces of Subsidiary Absorptive Capacity. Journal of Management Studies, 50(4), 646-672. doi: 10.1111/joms.12010

Schumpeter, J. A. (1928). The Instability of Capitalism. The Economic Journal, 38(151), 361-386. doi: $10.2307 / 2224315$

Schumpeter, J. A. (1939). Business cycles: A theoretical, historical and statistical analysis of the capitalist process. New York: McGraw-Hill Book Company.

Scott, W. R. (2008). Institutions and organizations: Ideas and interests. Thousand Oaks, CA: Sage Publications, Inc.

Tallman, S., \& Chacar, A. S. (2011). Knowledge Accumulation and Dissemination in MNEs: A PracticeBased Framework. Journal of Management Studies, 48(2), 278-304. doi: 10.1111/j.14676486.2010.00971.x

Utterback, J. M., \& Abernathy, W. J. (1975). A dynamic model of process and product innovation. Omega, 3(6), 639-656. doi: http://dx.doi.org/10.1016/0305-0483(75)90068-7

Uzzi, B. (1996). The Sources and Consequences of Embeddedness for the Economic Performance of Organizations: The Network Effect. American Sociological Review, 61(4), 674-698.

Uzzi, B., \& Gillespie, J. J. (2002). Knowledge spillover in corporate financing networks: embeddedness and the firm's debt performance. Strategic Management Journal, 23(7), 595-618. doi: 10.1002/smj. 241

Vernon-Wortzel, H., \& Wortzel, L. H. (1988). Globalizing strategies for multinationals from developing countries. Columbia Journal of World Business, 23(1), 27-36.

Vernon, R. (1966). International Investment and International Trade in the Product Cycle. Quarterly Journal of Economics, 80(2), 190-207.

Wu, X., Ma, R., \& Xu, G. (2009). Accelerating Secondary Innovation through Organizational Learning: A Case Study and Theoretical Analysis. Industry and Innovation, 16(4-5), 389-409. doi: 10.1080/13662710903053656

Yang, Q., Mudambi, R., \& Meyer, K. (2008). Conventional and Reverse Knowledge Flows in Multinational Corporations. Journal of Management, 34(5), 882-902.

Yip, G. S. (1989). Global strategy... In a world of nations? Sloan Management Review, 31(1), 29-41.

Zanfei, A. (2000). Transnational firms and the changing organisation of innovative activities. Cambridge Journal of Economics, 24(5), 515-542. doi: 10.1093/cje/24.5.515

Zhao, J., \& Richards, J. (2012). Beijing innovation system: the perspective of organisational structure and spatial distribution. Int. J. Learning and Intellectual Capital, 9(4), 413 - 428. doi: 10.1504/IJLIC.2012.049617

\section{FIGURES AND TABLES}

Table 1. Descriptive measures and correlation

\begin{tabular}{|c|c|c|c|c|c|c|}
\hline Variables & Mean & $\begin{array}{l}\text { Standard } \\
\text { deviation }\end{array}$ & 1 & 2 & 4 & 5 \\
\hline
\end{tabular}




\begin{tabular}{lllllll} 
1. H-S & 3,4214 & 0,68319 & 1 & & & \\
2. S-H & 3,0399 & 0,76012 & $0,434^{* *}$ & 1 & & \\
4. integration & 4,0078 & 0,72812 & $0,462 * *$ & $0,418^{* *}$ & 1 & \\
5. trust & 3,9998 & 0,64105 & $0,187^{*}$ & $0,346^{* *}$ & $0,606^{* *}$ & 1 \\
6. CIP & 3,7381 & 0,73041 & $-0,067$ & $-0,01$ & $-0,077$ & 0,007 \\
\hline Notes: * p<0.05 and ** & p $<0.01$ & & & &
\end{tabular}

Notes: $* \mathrm{p}<0.05$ and $* * \mathrm{p}<0.01$.

Source: The authors

Table 2. Regression Analysis

\begin{tabular}{lrrr}
\hline \multirow{2}{*}{ Variables } & \multicolumn{3}{c}{ Dependent variable } \\
\cline { 2 - 4 } & H-S & \multicolumn{3}{c}{$\mathrm{S}-\mathrm{H}$} & $\mathrm{VIF}$ \\
\cline { 2 - 4 } & \multicolumn{3}{c}{ Unstandardized coefficients (B) } \\
\hline Constant & 2,063 & 0,912 & \\
integration & $0,515^{* *}$ & $0,345^{* *}$ & 1,597 \\
trust & $-0,155 !$ & $0,173 !$ & 1,587 \\
$\mathrm{CIP}$ & $-0,022$ & 0,014 & 1,011 \\
$\mathrm{R}^{2}$ & 0,214 & 0,174 & \\
adjusted & 16,522 & 12,983 & \\
$\mathrm{~F}$ & & &
\end{tabular}

Notes: ! $<<0,10 * ; \mathrm{p}<0.05 ;$ and $* * \mathrm{p}<0.01$.

Source: The authors 